\title{
Communication \\ Use of Food Additive Titanium Dioxide (E171) before the Introduction of Regulatory Restrictions Due to Concern for Genotoxicity
}

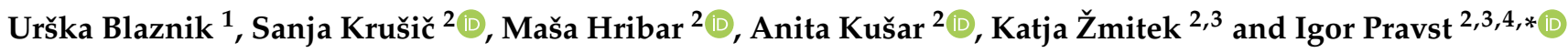 \\ 1 National Institute of Public Health, Trubarjeva 2, SI-1000 Ljubljana, Slovenia; urska.blaznik@nijz.si \\ 2 Nutrition Institute, Tržaška Cesta 40, SI-1000 Ljubljana, Slovenia; sanja.krusic@nutris.org (S.K.); \\ masa.hribar@nutris.org (M.H.); anita.kusar@nutris.org (A.K.); katja.zmitek@vist.si (K.Ž.) \\ VIST-Higher School of Applied Sciences, Gerbičeva Cesta 51A, SI-1000 Ljubljana, Slovenia \\ 4 Biotechnical Faculty, University of Ljubljana, Jamnikarjeva 101, SI-1000 Ljubljana, Slovenia \\ * Correspondence: igor.pravst@nutris.org; Tel.: +38-659-068-871
}

Citation: Blaznik, U.; Krušič, S.; Hribar, M.; Kušar, A.; Žmitek, K.; Pravst, I. Use of Food Additive Titanium Dioxide (E171) before the Introduction of Regulatory Restrictions Due to Concern for Genotoxicity. Foods 2021, 10, 1910. https://doi.org/10.3390/ foods10081910

Academic Editors: Isabel María Moreno Navarro and Juan D. Bautista Palomas

Received: 14 June 2021

Accepted: 13 August 2021

Published: 17 August 2021

Publisher's Note: MDPI stays neutral with regard to jurisdictional claims in published maps and institutional affiliations.

Copyright: (c) 2021 by the authors. Licensee MDPI, Basel, Switzerland. This article is an open access article distributed under the terms and conditions of the Creative Commons Attribution (CC BY) license (https:// creativecommons.org/licenses/by/ $4.0 /)$.

\begin{abstract}
Food-grade titanium dioxide $\left(\mathrm{TiO}_{2} ; \mathrm{E} 171\right)$ is a coloring food additive. In May 2021, a scientific opinion was published by the European Food Safety Authority concluding that $\mathrm{TiO}_{2}$ can no longer be considered as a safe food additive. Our aim was to investigate the trends in the use of $\mathrm{TiO}_{2}$ in the food supply. A case study was conducted in Slovenia using two nationally representative cross-sectional datasets of branded foods. Analysis was performed on $N=12,644$ foods (6012 and 6632 in 2017 and 2020, respectively) from 15 food subcategories where $\mathrm{TiO}_{2}$ was found as a food additive. A significant decrease was observed in the use of $\mathrm{TiO}_{2}(3.6 \%$ vs. $1.8 \% ; p<0.01) . \mathrm{TiO}_{2}$ was most often used in the chewing gum category (36.3\%) in 2017, and chocolate and sweets category $(45.9 \%)$ in 2020. Meanwhile, in 2017, the largest share of $\mathrm{TiO}_{2}$-containing foods was observed in the chewing gum category, namely, $70.3 \%$, and these products presented over $85 \%$ of the market share. In 2020 , only $24.6 \%$ of chewing gums contained $\mathrm{TiO}_{2}$, which accounted for only $3 \%$ of the market share. In conclusion, we showed an overall decrease in $\mathrm{TiO}_{2}$ use, even though it has not yet been officially removed from the list of authorized food additives.
\end{abstract}

Keywords: titanium dioxide; E171; food supply; nanoparticles; safety; Europe; Slovenia

\section{Introduction}

Titanium dioxide $\left(\mathrm{TiO}_{2}\right)$ is a transition metal oxide with application as a pigment or photocatalyst [1]. As a white pigment it has been added to a variety of food products, including bakery products, sauces, cheeses, edible ices and sweets. In addition to food, titanium dioxide is also used in medicinal products as an excipient, and in personal care products as a pigment and thickener [2,3], and can also be used as an UV filter in mineral sunscreen products $[4,5]$.

$\mathrm{TiO}_{2}$ was first approved for use in food in 1966 by the US Food and Drug Administration (FDA), with the stipulation that its content must not exceed $1 \%$ of the food weight [6]. On the basis of the Codex Alimentarius of the Food and Agriculture Organization/World Health Organization (FAO/WHO) [1] safety evaluation, $\mathrm{TiO}_{2}$ has been authorized as a food additive by the European Union (EU) with code E171 since 1969 [7]. Due to the presence of a fraction of nanoparticles, it falls under the scope of the EFSA Guidance on nanotechnology as "a material that is not engineered as nanomaterial but contains a fraction of particles, less than $50 \%$ in the number-size distribution, with one or more external dimensions in the size range 1-100 nm" [8]. E171 as a food additive consist of approximately $40 \%$ of $\mathrm{TiO}_{2}$ nanosized particles $(<100 \mathrm{~nm})$ and $60 \%$ of $\mathrm{TiO}_{2}$ microsized particles (>100 nm) [2,9,10]. As it was permitted for use in the EU before 20 January 2009, it belongs to the group of food additives that are subject to a safety re-evaluation by the 
European Food Safety Authority (EFSA), according to Commission Regulation (EU) No. 257/2010, and in line with the provision of Regulation (EC) No. 1333/2008 [11]. Therefore, the safety of $\mathrm{TiO}_{2}$ as a food additive was re-evaluated by the EFSA Panel on Food Additives and Nutrient Sources added to Food (ANS) [12] in 2016, on the basis of which the EFSA concluded that $\mathrm{TiO}_{2}$ did not raise concerns with respect to genotoxicity and carcinogenicity. Genotoxicity refers to the ability of a chemical substance to damage the genetic material of cells, which may lead to carcinogenic effects [13]. EFSA also recommended that additional studies be conducted to fill the gaps in possible effects on the reproductive system, which could lead to an established Acceptable Daily Intake (ADI) for $\mathrm{TiO}_{2}$. Therefore, in January 2017, the European Commission (EC) issued an open call for additional data for $\mathrm{TiO}_{2}$, including reproductive toxicity data. Several studies investigated the toxicity of dietary $\mathrm{TiO}_{2}[10,14-25]$, raising some concerns regarding its potential tumor-promoting activity. In 2018, the outcome of four specific studies $[10,14,20,23]$ was included in a scientific evaluation to determine the need to re-open the conclusion of the EFSA's opinion from 2016. However, the decision was taken in 2018 that the re-opening of this issue was not needed [26]. In April 2019, the French Agency for Food, Environmental and Occupational Health and Safety (ANSES) delivered a scientific opinion, based on 25 studies published between 2017 and 2019 [27], on the exposure to nanoparticles of $\mathrm{TiO}_{2}$, and highlighted that the previous EFSA assessment did not consider all available data. In response to this opinion [28], the EFSA noted that ANSES reiterated previously identified concerns and data gaps, and did not present findings that changed the Authority's previous conclusions on the safety of $\mathrm{TiO}_{2}$. Furthermore, the Office for Risk Assessment and Research of the Netherlands Food and Consumer Product Safety Authority (NVWA) delivered an opinion on possible health effects of $\mathrm{TiO}_{2}$ in 2019 [29], highlighting the possible immune and reproductive toxicological effects of $\mathrm{TiO}_{2}$. While further activities were underway to obtain new data, the French Government followed the precautionary principle, based on the opinion of the ANSES in 2019 [27], and decided to ban $\mathrm{TiO}_{2}$ in food products starting on 1 January 2020. Just a few days after this decision was announced, a joint letter to the EC [30] was published to EC, with civil society organizations requesting to remove $\mathrm{TiO}_{2}$ from the EU list of permitted food additives. Following the request of the EC in March 2020, the EFSA started an additional safety evaluation of this additive. An in-depth safety assessment report for the $\mathrm{TiO}_{2}$ was published on 6 May 2021 [31]. The EFSA panel concluded that with consideration of the available evidence, a concern for genotoxicity could not be excluded and, therefore, $\mathrm{TiO}_{2}$ could no longer be considered as a safe food additive.

As mentioned, several studies have addressed the question of toxicity of E171. Studies on rats and mice have shown that nanoparticles can pass through the intestinal barrier, accumulate in the intestine and cause preneoplastic lesions [14,32], promote anxiety, increase the number of adenomas in the colon, induce hypertrophy and hyperplasia in goblet cells [33] and disrupt gut microbiota composition and function [34-38]. Accumulation and toxic effects have also been found in plants [39,40]. However, health aspects of E171 oral intake by consumers in a real exposure environment still need to be confirmed by further research.

Food additives are an important part of processed foods. Consumers have expressed concern for some time about their possible adverse health effects [41] and would like to be better informed about their potential health implications [42,43]. EU Member States, and the EC as risk managers, request the EFSA to provide independent scientific advice, which informs European food policy makers. In the next step, the EFSA's scientific advice on $\mathrm{TiO}_{2}$ will be used to support further regulatory procedures and decisions. The most realistic outcome is that the use of $\mathrm{TiO}_{2}$ as a food additive will not be approved in the EU in the near future.

The objective of this study was to evaluate the prevalence and changes in the use of $\mathrm{TiO}_{2}$ as a food additive in the food supply since 2017, when the EC issued an open call for additional toxicity data for $\mathrm{TiO}_{2}$. The Slovenian food supply was selected for a case study, using nationally representative cross-sectional data on the composition of prepacked 
foods in 2017 and 2020 collected within the national "Nutrition and Public Health" research program and the "Food Nutrition Security Cloud" project (FNS-Cloud; www.fns-cloud.eu, accessed: 15 August 2021).

\section{Materials and Methods}

\subsection{Data Collection and Categorization}

The study was conducted on a sample of prepacked foods available in Slovenia, EU. The food supply sample was collected in 2017 and 2020 in major retail shops representing the majority of the food market, and was part of the Composition and Labelling Information System (CLAS, Nutrition Institute, Ljubljana, Slovenia) [44]. In both years, data collection was done in retail shops of Mercator, Spar, Tuš, Lidl, Hofer, while in 2020 we also included retailer Eurospin. The dataset was prepared by the extraction of food labelling information from photographs of all branded foods available in selected food stores at the time of collection. Data were collected with the aim of monitoring the nutritional composition of processed foods in the food supply [45], with the adaptation that we also collected ingredient lists. The detailed methodology of the data collection is described elsewhere $[46,47]$.

Foods were classified into food categories according to Global Food Monitoring Group (GFMG) recommendations [45], with minor modifications [46,47]. Without food supplements, food additives sold to consumers in food stores and food that did not fit into any of the GFMG food groups, our dataset contained 49,919 prepacked food items; 23,690 and 26,229 from 2017 and 2020 monitoring, respectively. For 10,034 products (42\%) in the 2017 dataset, there was a matching product with same International/European Article Number (EAN) barcode in the 2020 dataset. We identified all foods in this dataset, where the ingredient list text contained the terms " $\mathrm{TiO}_{2}$ ", "E171" and/or "titanium (di)oxide".

Food (sub)categories that contained foods with $\mathrm{TiO}_{2}$ as a food additive at least in one sampled year and were further investigated in this study are as follows: biscuits; cakes, muffins and pastry; canned fish with vegetables; chewing gum; chocolate and sweets; cordials; desserts; flavored yogurt; ice cream and edible ices; jelly; processed fish products; side dishes; soup; spreads and processed cheese; and sugar. Our total study sample, therefore, included between 12.664 and 6.012 foods for 2017, of which 215 contained $\mathrm{TiO}_{2}$ (3.6\%), and 6.632 foods for 2020, of which $122(1.8 \%)$ contained $\mathrm{TiO}_{2}$.

\subsection{Data Processing and Statistical Analyses}

Food composition data were processed using Microsoft SQL Server Management Studio 13.0, Microsoft Analysis Services Client Tools 13.0, Microsoft Data Access Components (MDAC) 10.0, Microsoft Excel 2019 (Microsoft, Redmond, Washington, DC, USA) and the Composition and Labelling Information System (CLAS) (Nutrition Institute, Ljubljana, Slovenia). Statistical analyses were performed using Microsoft Excel 2019 (Microsoft, Redmond, Washington, DC, USA).

For statistical evaluation, we calculated proportions of $\mathrm{TiO}_{2}$-containing foods in different food (sub)categories. Additionally, we calculated the within-category proportion of foods containing $\mathrm{TiO}_{2}$, which was corrected with product market shares using the previously described sale-weighting approach [47]. In the investigated food categories, market share data were available for 59.8\% $(N=3597)$ and $54.2 \%$ of foods $(N=3597)$ for 2017 and 2020, respectively. Sale-weighted proportions of $\mathrm{TiO}_{2}$-containing foods were calculated for each (sub)category separately, using the EAN barcode as a unique product identifier, with consideration of product packaging quantity and number of sold products in a 12-month period (based on nationwide sales data provided by food retailers). Food subcategories with less than four $\mathrm{TiO}_{2}$-containing foods were excluded from this analysis.

Descriptive analysis was used for proportions of food that contained $\mathrm{TiO}_{2}$, and the $95 \%$ confidence interval (95\% CI) was calculated employing the Wilson score interval [48]. A two-tailed z-test was used to identify differences in the use of $\mathrm{TiO}_{2}$ between 2017 and 2020 . The level of significance was set at $p<0.05$. The following subcategories were excluded from 
this part of the analysis due to their low sample size of foods containing $\mathrm{TiO}_{2}$ : processed fish products; canned fish with vegetable; sugar; ice cream and edible ices; desserts; flavored yogurt; cordials; soup; biscuits; side dishes and spreads and processed cheese.

\section{Results and Discussion}

The study was conducted on a sample of 6012 foods and beverages in 2017, and 6632 foods and beverages in 2020. Within the 15 selected food subcategories, 13 categories contained $\mathrm{TiO}_{2}$ in 2017 (215 products), and 10 categories in 2020 (122 products). In 2017, foods containing the highest amount of $\mathrm{TiO}_{2}$ were distributed in the chewing gum category, accounting for more than a third $(36.3 \%)$ of the total amount of $\mathrm{TiO}_{2}$-containing foods (Figure 1). The second third was represented by chocolates and sweets $(32.6 \%)$, followed by cakes, muffins and pastry (11.6\%), jelly $(8.4 \%)$ and processed fish products $(2.3 \%)$. In 2020 , almost half of $\mathrm{TiO}_{2}$ was distributed in the chocolate and sweets category $(45.9 \%)$ and one third in the chewing gum category $(27.9 \%)$, followed by cakes, muffins and pastry $(9.0 \%)$, jelly $(5.7 \%)$ and processed fish products $(4.9 \%)$ (Figure 1$)$. The remaining categories (each with less than a 3\% share) represented $9 \%$ and $7 \%$ of $\mathrm{TiO}_{2}$-containing foods in 2017 and 2020, respectively (Figure 1, "Other").
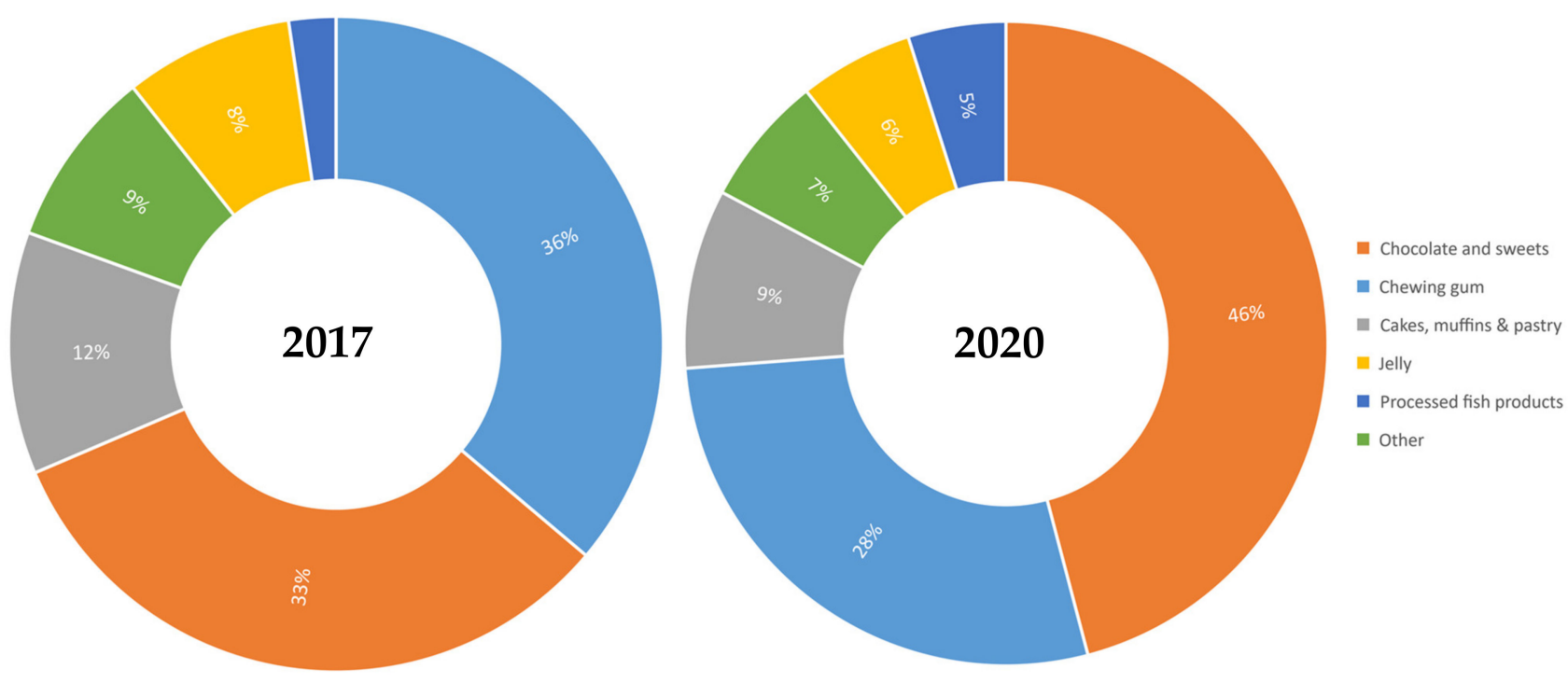

Figure 1. Distribution of foods containing $\mathrm{TiO}_{2}$ per food (sub)category in 2017 versus 2020.

To provide insights into food reformulation practices, we also compared the composition of foods, which were found in both 2017 and 2020 dataset. Food matching using EAN barcodes resulted in 10,034 foods available in both datasets. Altogether, 88 of these products contained $\mathrm{TiO}_{2}$ in the 2017 sample, while in 2020 the use of $\mathrm{TiO}_{2}$ was retained in 49 products $(55.7 \%)$. This indicates that food reformulation (removal of $\mathrm{TiO}_{2}$ ) was observed in $44.3 \%(N=39)$ products.

Furthermore, we calculated per-category proportions of $\mathrm{TiO}_{2}$-containing foods in the food supply for both 2017 and 2020 (Table 1). For each year, we calculated the (nonweighted) proportion as a percentage of $\mathrm{TiO}_{2}$-containing foods of all available foods in the category. To gain an insight into the availability of such foods with a consideration of market share, we further employed the sale-weighting approach using nationwide 12-month sales data, provided by the largest food retailers in Slovenia. Such an approach provided information on whether $\mathrm{TiO}_{2}$ was used in market-leading brands or mostly in niche products. It should be noted that sales data were available for most, but not all foods in our study sample (see Section 2.1 for details). Missing data mostly reflect availability in discounter retailers. 
Table 1. (Sub)category proportions of foods containing $\mathrm{TiO}_{2}$ (E171) as food additive in the food supply for 2017 and 2020 (Slovenia).

\begin{tabular}{|c|c|c|c|c|c|c|c|c|c|c|}
\hline \multirow[b]{2}{*}{ Food Category } & \multicolumn{4}{|c|}{2017} & \multicolumn{4}{|c|}{2020} & \multicolumn{2}{|c|}{$z$-Test Statistic for Proportions } \\
\hline & Total $N$ & Added $\mathrm{TiO}_{2} N$ & $\%(95 \% \mathrm{CI})$ & $\begin{array}{l}\text { Sale-Weighted } \\
\text { Proportion (\%) }\end{array}$ & Total $N$ & Added $\mathrm{TiO}_{2} \mathrm{~N}$ & $\%(95 \% \mathrm{CI})$ & $\begin{array}{l}\text { Sale-Weighted } \\
\text { Proportion (\%) }\end{array}$ & $\begin{array}{c}\text { Proportion Change } \\
(95 \% \mathrm{CI})\end{array}$ & $p$-Value \\
\hline Chewing gum & 111 & 78 & $70.3(61.8-78.8)$ & 85.5 & 138 & 34 & $24.6(17.4-31.8)$ & 3.1 & $45.6(34.5-56.8)$ & $<0.01$ \\
\hline Processed fish products & 71 & 5 & $7.0(1.1-13.0)$ & 19.3 & 87 & 6 & $6.9(1.6-12.2)$ & 19.0 & $0.1(-7.8-8.1)$ & $\mathrm{ns}$ \\
\hline Cakes, muffins and pastry & 569 & 25 & $4.4(2.7-6.1)$ & 3.0 & 639 & 11 & $1.7(0.7-2.7)$ & 1.1 & $2.7(0.7-4.6)$ & $<0.01$ \\
\hline Chocolate and sweets & 1917 & 70 & $3.7(2.9-4.5)$ & 2.8 & 2173 & 56 & $2.6(1.9-3.2)$ & 1.1 & $1.1(0.0-2.1)$ & 0.02 \\
\hline Canned fish with vegetable & 60 & 1 & $1.7(0.3-8.9)$ & $*$ & 60 & 0 & & & & ns \\
\hline Sugar & 127 & 2 & $1.6(0.4-5.6)$ & * & 108 & 0 & & & & ns \\
\hline Desserts & 207 & 2 & $1.0(0.4-2.3)$ & $*$ & 298 & 0 & & & & ns \\
\hline Flavored yogurt & 419 & 3 & $0.7(0.2-2.1)$ & * & 386 & 0 & & & & $\mathrm{~ns}$ \\
\hline Cordials & 179 & 1 & $0.6(0.1-3.1)$ & * & 190 & 0 & & & & ns \\
\hline Soup & 264 & 1 & $0.4(0.1-2.1)$ & * & 257 & 1 & $0.4(0.1-2.2)$ & * & $0.0(-1.1-1.1)$ & $\mathrm{ns}$ \\
\hline Biscuits & 1035 & 3 & $0.3(0.1-0.9)$ & * & 1122 & 2 & $0.2(0.1-0.6)$ & * & $0.1(-0.2-0.5)$ & ns \\
\hline Side dishes & 199 & 0 & & & 224 & 1 & $0.5(0.1-2.5)$ & * & & ns \\
\hline Spreads and processed cheese & 238 & 0 & & & 205 & 1 & $0.5(0.1-2.7)$ & * & & ns \\
\hline Total & 6012 & 215 & $3.6(3.1-4.0)$ & na & 6632 & 122 & $1.8(1.5-2.2)$ & na & $1.8(1.1-2.3)$ & $<0.01$ \\
\hline
\end{tabular}

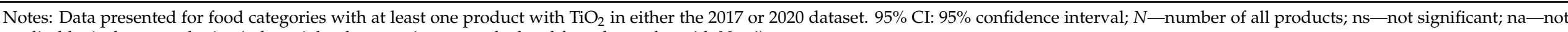
applicable; *-low sample size (sale-weighted proportions not calculated for subsamples with $N<4$ ). 
Per-category, nonweighted proportions of $\mathrm{TiO}_{2}$-containing foods represented up to $70.3 \%$ in 2017 (Table 1). In 2017, the largest share of $\mathrm{TiO}_{2}$-containing foods was represented by chewing gum, comprising more than two third of the sample (70.3\%), followed by jelly $(9.7 \%)$ and processed fish products $(7.0 \%)$ (Table 1$)$. Chewing gum was also the highest ranked category $(24.6 \%)$ in 2020 , followed by processed fish products $(6.9 \%)$ and jelly $(4.4 \%)$.

In 2017, the sale-weighted proportion of $\mathrm{TiO}_{2}$-containing chewing gums was higher than the nonweighted proportion ( $85.5 \%$ vs. $70.3 \%$ ), showing that this food additive was present in major brands. The situation changed considerably in 2020, when the saleweighted proportion was much lower (3.1\% vs. $24.6 \%)$. This indicates that a decrease in the use of $\mathrm{TiO}_{2}$ was even more pronounced in the best-selling products. We also compared the composition of the chewing gums, which contained $\mathrm{TiO}_{2}$ in 2017, and were still marketed in 2020. Out of 44 such products, $25(56.8 \%)$ no longer contained $\mathrm{TiO}_{2}$ in 2020. This indicates that $\mathrm{TiO}_{2}$ dropped not only because of the arrival of new $\left(\mathrm{TiO}_{2}{ }^{-}\right.$ free) products and removal of older $\left(\mathrm{TiO}_{2}\right.$-containing) products from the market, but also because of the reformulation of the existing products. However, the differences between sale-weighted and nonweighted proportions in other food categories were expressed to a much lower extent. Beside chewing gums, food subcategories with the highest saleweighted proportions of foods with $\mathrm{TiO}_{2}$ were jelly $(14.8 \%)$ and processed fish products $(19.3 \%)$ in 2017 . Considerably high sale-weighted proportions were also observed in these two categories in 2020 (20.2\% and $19.0 \%$, respectively).

The overall comparison of the 2017 and 2020 data showed a significant $(p<0.01)$ decrease in the use of $\mathrm{TiO}_{2}$ as a food additive from 2017 to 2020 . Across the 15 observed food subcategories, $3.6 \%$ foods contained $\mathrm{TiO}_{2}$ in 2017 , and $1.8 \%$ in 2020 . This change could be attributed to the availability of new evidence on the potential health risks of $\mathrm{TiO}_{2}$, and by concerns raised by national health authority agencies $[27,29]$. As health concerns were also raised by EFSA [31], it is expected that responsible food producers will remove it from their products, despite the fact that it has not yet been officially restricted from the EU food supply. A statistically significant decrease in the use of $\mathrm{TiO}_{2}$ was also observed in specific food categories where $\mathrm{TiO}_{2}$ was a relevant additive in 2017. Sale-weighted proportions showed a similar trend, with the exception of the abovementioned processed fish products and jelly.

To our knowledge, this is the first repeated cross-sectional study on the use of $\mathrm{TiO}_{2}$ in the food supply in which trends in the use of $\mathrm{TiO}_{2}$ in prepacked foods were investigated with consideration of market share data. Such methodology makes the study results particularly relevant for the assessment of public health risks. While this makes comparisons with other studies difficult, relevant comparisons can be performed without consideration of sale-weighting. Mintel's Global New Products Database (GNPD) [49], which contains data of newly launched foods in different countries (but not Slovenia), was used in the recent safety assessment of $\mathrm{TiO}_{2}$ by EFSA [31]. For a more relevant comparison, we combined several of Mintel's food subcategories [50]. The highest proportion of $\mathrm{TiO}_{2}{ }^{-}$ containing foods was observed in chewing gums (39\%), followed by pastilles, gums, jellies and chews (10\%), cakes, pastries and desserts (4\%); and chocolate and sweets (3\%) [31]. The Mintel database cannot be considered as cross-sectional, as it only contains data on newly launched products on the market (and not the overall situation in the food supply, where some market-leading brands have a long history of availability). Nevertheless, it should be mentioned that a decreasing trend in the use of $\mathrm{TiO}_{2}$ in newly launched foods was also observed. Data are also available for the US, where $\mathrm{TiO}_{2}$ was most commonly used in nonchocolate candy (32\%), followed by cupcakes and snack cakes (14\%), cookies $(8 \%)$, coated pretzels and trail mix $(7 \%)$, baking decorations $(6 \%)$, gum and mints $(4 \%)$ and ice cream (2\%). However, it was assumed that many other foods contain $\mathrm{TiO}_{2}$, because in the US market $\mathrm{TiO}_{2}$ can be considered as an exempt color that does not require explicit declaration on the ingredient statement [51]. 
Exposure to $\mathrm{TiO}_{2}$ largely depends on an individual's dietary habits. Since $\mathrm{TiO}_{2}$ is mainly present in processed foods such as chewing gum, cakes, pastry and other sweets, children and young people are more likely to be more exposed to higher $\mathrm{TiO}_{2}$ intake. For the United Stated and United Kingdom population it has been calculated that children potentially consumed two to four times as much $\mathrm{TiO}_{2}$ per $\mathrm{kg}$ body weight as an adult [2] Similar studies revealing that children consume higher amount of $\mathrm{TiO}_{2}$ were observed across Europe [52] in the German and [53] Dutch population [21,54], and among Chinese young people [55].

Given scrutiny from regulatory bodies, the food industry has been working on $\mathrm{TiO}_{2}$ alternatives for some years. Reformulation initiatives were also stimulated by various nongovernmental active groups. In the US, for example, the As You Sow group put pressure on the Dunkin' brand, which then withdrew the use of $\mathrm{TiO}_{2}$ from their sugar powdered donuts [56]. However, replacing $\mathrm{TiO}_{2}$ across all applications is technologically very challenging, as $\mathrm{TiO}_{2}$ is not only an excellent whitening pigment but also very cost effective [51]. However, rice starches now offer clean label solutions that can help with reducing the chipping and cracking of coatings [51]. Avalanche, starch and mineral based white opacifier are the most common replacements for $\mathrm{TiO}_{2}$ in food applications [57].

The strength of the present study is in the use of two large nationally representative cross-sectional food composition datasets in combination with market shares. While such an approach was used in the past for the assessment of public health risks related to specific nutrients, such as salt [58] and sugar [47], we showed that it can also be employed for food additives. The limitation of the study is that the used dataset did not contain all available foods, and that sales data were not available for the whole dataset. However, we should mention that data collection included all major retailers with a nationwide network of food stores, and that sales data were available from retailers who are responsible for over $50 \%$ of the food market. Another limitation is that the data on the use of $\mathrm{TiO}_{2}$ were extracted from food labels, and not determined in a laboratory. However, regulations require the labeling of functional additives, and the laboratory analysis of thousands of foods is not a feasible option in food supply studies. We should also note that our study did not investigate certain groups of foods in which a higher use of coloring agents could be expected, such as food supplements and food additive products (i.e., foods sold directly to consumers which are intended for coloring), which are also available to consumers in food stores.

\section{Conclusions}

According to the results of our study, the availability of prepackaged food products in Slovenia has undergone several improvements regarding the use of $\mathrm{TiO}_{2}$ in certain food categories. This is particularly notable in the category of chewing gum, where a reformulation trend was also observed. In recent years, we have witnessed an increased regulatory scrutiny of $\mathrm{TiO}_{2}$ as a food additive. In other studies, this was reflected in a decline in new launches of foods containing $\mathrm{TiO}_{2}$, while this cross-sectional study also confirmed such an observation in a whole supply of processed foods in Slovenia. We observed that in the past, the category with the most common use of $\mathrm{TiO}_{2}$ was chewing gum. In 2017, approximately $70 \%$ of chewing gums contained $\mathrm{TiO}_{2}$, and these products presented over $85 \%$ of the market share (by weight). However, the situation changed drastically; in 2020, approximately $25 \%$ of chewing gums contained $\mathrm{TiO}_{2}$, accounting for only $3 \%$ of the market share. The other two food categories with a high use of $\mathrm{TiO}_{2}$ were jelly and processed fish products, while in other food categories, less than $3 \%$ of products contained $\mathrm{TiO}_{2}$. Considering the EFSA's 2021 announcement of $\mathrm{TiO}_{2}$ no longer being safe to use, a further decrease in the use of this additive is expected despite the fact that it has not yet been officially removed from the list of authorized food additives in the EU. Specific food categories were identified (i.e., chocolate and sweets), in which product reformulation is needed, and official controls by authorities will be most relevant. 
Author Contributions: Conceptualization, I.P.; data collection, M.H., S.K. and U.B.; methodology, I.P. and U.B.; formal analysis, S.K.; writing-original draft preparation, I.P., S.K. and U.B.; manuscript writing-review and editing, all authors; manuscript review, A.K. and K.Ž. All authors have read and agreed to the published version of the manuscript.

Funding: Data collection for this study was supported by the national research program "Nutrition and Public Health" (P3-0395, funded by the Slovenian Research Agency), and the Food Nutrition Security Cloud project (FNS-Cloud), which received funding from the European Union's Horizon 2020 Research and Innovation program (H2020-EU.3.2.2.3.- a sustainable and competitive agrifood industry) under grant agreement No. 863059. Information and views in this report do not necessarily reflect the official opinion or position of the European Union. Neither the European Union institutions and bodies nor any person acting on their behalf may be held responsible for the use of the information contained herein.

Institutional Review Board Statement: Not applicable.

Informed Consent Statement: Not applicable.

Data Availability Statement: The data presented in this study are available on request from the corresponding author.

Acknowledgments: The authors would like to thank the retailers for granting access to their stores to collect data for the study. We also acknowledge collaborating researchers at the Nutrition Institute and students from the Biotechnical Faculty (University of Ljubljana) and BIC (Ljubljana) for their help in the data collection.

Conflicts of Interest: The authors declare no conflict of interest. The funders had no role in the design of the study; in the collection, analyses or interpretation of data; in the writing of the manuscript; or in the decision to publish the results. Igor Pravst has led and participated in various other research projects in the fields of nutrition, public health and food technology, which were (co)funded by the Slovenian Research Agency; the Ministry of Health of the Republic of Slovenia; the Ministry of Agriculture, Forestry and Food of the Republic of Slovenia; and in the case of specific applied research projects, also by food businesses.

\section{References}

1. Ropers, M.-H.; Terrisse, H.; Mercier-Bonin, M.; Humbert, B. Titanium Dioxide as Food Additive; IntechOpen: Rijeka, Croatia, 2017.

2. Weir, A.; Westerhoff, P.; Fabricius, L.; Hristovski, K.; Von Goetz, N. Titanium dioxide nanoparticles in food and personal care products. Environ. Sci. Technol. 2012, 46, 2242-2250. [CrossRef]

3. Peters, R.J.; van Bemmel, G.; Herrera-Rivera, Z.; Helsper, H.P.; Marvin, H.J.; Weigel, S.; Tromp, P.C.; Oomen, A.G.; Rietveld, A.G.; Bouwmeester, H. Characterization of titanium dioxide nanoparticles in food products: Analytical methods to define nanoparticles. J. Agric. Food Chem. 2014, 62, 6285-6293. [CrossRef]

4. Kullavanijaya, P.; Lim, H.W. Photoprotection. J. Am. Acad. Dermatol. 2005, 52, 937-958. [CrossRef]

5. Lautenschlager, S.; Wulf, H.C.; Pittelkow, M.R. Photoprotection. Lancet Lond. Engl. 2007, 370, 528-537. [CrossRef]

6. United States Food and Drug Administration. Summary of Color Additives for Use in the United States in Foods, Drugs, Cosmetics, and Medical Devices. 2017. Available online: https://www.fda.gov/industry/color-additive-inventories/summarycolor-additives-use-united-states-foods-drugs-cosmetics-and-medical-devices (accessed on 17 August 2021).

7. European Commission. Commission (EC) No 1333/2008 of the European Parliament and of the Council of 16 December 2008 on Food Additives. Off. J. Eur. Union 2011, L354/16, 1-18.

8. $\quad$ EFSA Scientific Committee; Hardy, A.; Benford, D.; Halldorsson, T.; Jeger, M.J.; Knutsen, H.K.; More, S.; Naegeli, H.; Noteborn, H.; Ockleford, C.; et al. Guidance on risk assessment of the application of nanoscience and nanotechnologies in the food and feed chain: Part 1, human and animal health. EFSA J. 2018, 16, e05327. [CrossRef]

9. Dorier, M.; Béal, D.; Marie-Desvergne, C.; Dubosson, M.; Barreau, F.; Houdeau, E.; Herlin-Boime, N.; Carriere, M. Continuous in vitro exposure of intestinal epithelial cells to E171 food additive causes oxidative stress, inducing oxidation of DNA bases but no endoplasmic reticulum stress. Nanotoxicology 2017, 11, 751-761. [CrossRef] [PubMed]

10. Proquin, H.; Rodríguez-Ibarra, C.; Moonen, C.G.; Urrutia Ortega, I.M.; Briedé, J.J.; de Kok, T.M.; van Loveren, H.; Chirino, Y.I. Titanium dioxide food additive (E171) induces ROS formation and genotoxicity: Contribution of micro and nano-sized fractions. Mutagenesis 2017, 32, 139-149. [CrossRef] [PubMed]

11. European Comission. Commission Regulation (EU) No 257/2010 of 25 March 2010 setting up a programme for the re-evaluation of approved food additives in accordance with Regulation (EC) No 1333/2008 of the European Parliament and of the Council on food additives. Off. J. Eur. Union 2010, L80/19, 1-9.

12. EFSA Panel on Food Additives Nutrient Sources added to Food. Re-evaluation of titanium dioxide (E 171) as a food additive. EFSA J. 2016, 14, 83. [CrossRef] 
13. Maurici, D.; Aardema, M.; Corvi, R.; Kleber, M.; Krul, C.; Laurent, C.; Loprieno, N.; Pasanen, M.; Pfuhler, S.; Phillips, B.; et al. Genotoxicty and mutagenicity. Altern. Lab. Anim. ATLA 2005, 33 (Suppl. S1), 117-130. [CrossRef] [PubMed]

14. Bettini, S.; Boutet-Robinet, E.; Cartier, C.; Coméra, C.; Gaultier, E.; Dupuy, J.; Naud, N.; Taché, S.; Grysan, P.; Reguer, S.; et al. Food-grade $\mathrm{TiO}(2)$ impairs intestinal and systemic immune homeostasis, initiates preneoplastic lesions and promotes aberrant crypt development in the rat colon. Sci. Rep. 2017, 7, 40373. [CrossRef]

15. Chen, X.X.; Cheng, B.; Yang, Y.X.; Cao, A.; Liu, J.H.; Du, L.J.; Liu, Y.; Zhao, Y.; Wang, H. Characterization and preliminary toxicity assay of nano-titanium dioxide additive in sugar-coated chewing gum. Small Weinh. Bergstr. Ger. 2013, 9, 1765-1774. [CrossRef] [PubMed]

16. Athinarayanan, J.; Alshatwi, A.A.; Periasamy, V.S.; Al-Warthan, A.A. Identification of nanoscale ingredients in commercial food products and their induction of mitochondrially mediated cytotoxic effects on human mesenchymal stem cells. J. Food Sci. 2015, 80, N459-N464. [CrossRef] [PubMed]

17. Tassinari, R.; Cubadda, F.; Moracci, G.; Aureli, F.; D'Amato, M.; Valeri, M.; De Berardis, B.; Raggi, A.; Mantovani, A.; Passeri, D.; et al. Oral, short-term exposure to titanium dioxide nanoparticles in Sprague-Dawley rat: Focus on reproductive and endocrine systems and spleen. Nanotoxicology 2014, 8, 654-662. [CrossRef] [PubMed]

18. Jovanović, B. Critical review of public health regulations of titanium dioxide, a human food additive. Integr. Environ. Assess. Manag. 2015, 11, 10-20. [CrossRef]

19. Periasamy, V.S.; Athinarayanan, J.; Al-Hadi, A.M.; Juhaimi, F.A.; Mahmoud, M.H.; Alshatwi, A.A. Identification of titanium dioxide nanoparticles in food products: Induce intracellular oxidative stress mediated by TNF and CYP1A genes in human lung fibroblast cells. Environ. Toxicol. Pharmacol. 2015, 39, 176-186. [CrossRef]

20. Heringa, M.B.; Geraets, L.; van Eijkeren, J.C.; Vandebriel, R.J.; de Jong, W.H.; Oomen, A.G. Risk assessment of titanium dioxide nanoparticles via oral exposure, including toxicokinetic considerations. Nanotoxicology 2016, 10, 1515-1525. [CrossRef]

21. Rompelberg, C.; Heringa, M.B.; van Donkersgoed, G.; Drijvers, J.; Roos, A.; Westenbrink, S.; Peters, R.; van Bemmel, G.; Brand, W.; Oomen, A.G. Oral intake of added titanium dioxide and its nanofraction from food products, food supplements and toothpaste by the Dutch population. Nanotoxicology 2016, 10, 1404-1414. [CrossRef]

22. Farrell, T.P.; Magnuson, B. Absorption, Distribution and Excretion of Four Forms of Titanium Dioxide Pigment in the Rat. J. Food Sci. 2017, 82, 1985-1993. [CrossRef]

23. Guo, Z.; Martucci, N.J.; Moreno-Olivas, F.; Tako, E.; Mahler, G.J. Titanium Dioxide Nanoparticle Ingestion Alters Nutrient Absorption in an In Vitro Model of the Small Intestine. NanoImpact 2017, 5, 70-82. [CrossRef] [PubMed]

24. Jia, X.; Wang, S.; Zhou, L.; Sun, L. The Potential Liver, Brain, and Embryo Toxicity of Titanium Dioxide Nanoparticles on Mice. Nanoscale Res. Lett. 2017, 12, 478. [CrossRef] [PubMed]

25. Pinget, G.; Tan, J.; Janac, B.; Kaakoush, N.O.; Angelatos, A.S.; O’Sullivan, J.; Koay, Y.C.; Sierro, F.; Davis, J.; Divakarla, S.K.; et al. Impact of the Food Additive Titanium Dioxide (E171) on Gut Microbiota-Host Interaction. Front. Nutr. 2019, 6, 57. [CrossRef]

26. EFSA Panel on Food Additives and Nutrient Sources added to Food; Younes, M.; Aggett, P.; Aguilar, F.; Crebelli, R.; Dusemund, B.; Filipič, M.; Frutos, M.J.; Galtier, P.; Gott, D.; et al. Evaluation of four new studies on the potential toxicity of titanium dioxide used as a food additive (E 171). EFSA J. 2018, 16, e05366. [CrossRef] [PubMed]

27. French Agency for Food Environmental and Occupational Health \& Safety. AVIS de l'Agence Nationale de Sécurité Sanitaire de L'alimentation, de L'environnement et du Travail Relatif aux Risques Liés à L'ingestion de L'additif Alimentaire E171; Saisine $\mathrm{n}$ 2019-SA-0036; Anses: Buenos Aires, Argentina, 2019; pp. 1-44.

28. EFSA. EFSA statement on the review of the risks related to the exposure to the food additive titanium dioxide (E 171) performed by the French Agency for Food, Environmental and Occupational Health and Safety (ANSES). EFSA J. 2019, 17, e05714. [CrossRef]

29. Netherlands Food and Consumer Product Safety Authority (NVWA). Opinion of BuRO on Possible Health Effects of the Food Additive Titanium Dioxide (E171). Available online: https:/ / english.nvwa.nl/documents/consumers/food/safety/documents/ opinion-of-buro-on-possible-health-effects-of-the-food-additive-titanium-dioxide-e171 (accessed on 17 August 2021).

30. Civil society organisations, Civil Society Organisations Demand the Removal of E171 from the EU List of Permitted Food Additives. Available online: https://www.beuc.eu/publications/beuc-x-2019-031_removal_of_e171_from_the_eu_list_of_ permitted_food_additives.pdf (accessed on 17 August 2021).

31. EFSA Panel on Food Additives and Flavourings; Younes, M.; Aquilina, G.; Castle, L.; Engel, K.-H.; Fowler, P.; Frutos Fernandez, M.J.; Fürst, P.; Gundert-Remy, U.; Gürtler, R.; et al. Safety assessment of titanium dioxide (E171) as a food additive. EFSA J. 2021, 19, e06585. [CrossRef]

32. Dudefoi, W.; Moniz, K.; Allen-Vercoe, E.; Ropers, M.-H.; Walker, V.K. Impact of food grade and nano-TiO2 particles on a human intestinal community. Food Chem. Toxicol. 2017, 106, 242-249. [CrossRef]

33. Medina-Reyes, E.I.; Delgado-Buenrostro, N.L.; Díaz-Urbina, D.; Rodríguez-Ibarra, C.; Déciga-Alcaraz, A.; González, M.I.; Reyes, J.L.; Villamar-Duque, T.E.; Flores-Sánchez, M.L.O.; Hernández-Pando, R.; et al. Food-grade titanium dioxide (E171) induces anxiety, adenomas in colon and goblet cells hyperplasia in a regular diet model and microvesicular steatosis in a high fat diet model. Food Chem. Toxicol. 2020, 146, 111786. [CrossRef] [PubMed]

34. Perez, L.; Scarcello, E.; Ibouraadaten, S.; Yakoub, Y.; Leinardi, R.; Ambroise, J.; Bearzatto, B.; Gala, J.-L.; Paquot, A.; Muccioli, G.G.; et al. Dietary nanoparticles alter the composition and function of the gut microbiota in mice at dose levels relevant for human exposure. Food Chem. Toxicol. 2021, 154, 112352. [CrossRef] 
35. Agans, R.T.; Gordon, A.; Hussain, S.; Paliy, O. Titanium Dioxide Nanoparticles Elicit Lower Direct Inhibitory Effect on Human Gut Microbiota Than Silver Nanoparticles. Toxicol. Sci. 2019, 172, 411-416. [CrossRef]

36. Chen, Z.; Han, S.; Zhou, D.; Zhou, S.; Jia, G. Effects of oral exposure to titanium dioxide nanoparticles on gut microbiota and gut-associated metabolism in vivo. Nanoscale 2019, 11, 22398-22412. [CrossRef]

37. Li, M.; Li, F.; Lu, Z.; Fang, Y.; Qu, J.; Mao, T.; Wang, H.; Chen, J.; Li, B. Effects of TiO2 nanoparticles on intestinal microbial composition of silkworm, Bombyx mori. Sci. Total Environ. 2020, 704, 135273. [CrossRef]

38. Zhang, S.; Jiang, X.; Cheng, S.; Fan, J.; Qin, X.; Wang, T.; Zhang, Y.; Zhang, J.; Qiu, Y.; Qiu, J.; et al. Titanium dioxide nanoparticles via oral exposure leads to adverse disturbance of gut microecology and locomotor activity in adult mice. Arch. Toxicol. 2020, 94, 1173-1190. [CrossRef]

39. Giorgetti, L.; Spanò, C.; Muccifora, S.; Bellani, L.; Tassi, E.; Bottega, S.; Di Gregorio, S.; Siracusa, G.; Sanità di Toppi, L.; Ruffini Castiglione, M. An integrated approach to highlight biological responses of Pisum sativum root to nano-TiO $\mathrm{O}_{2}$ exposure in a biosolid-amended agricultural soil. Sci. Total Environ. 2019, 650, 2705-2716. [CrossRef]

40. Bellani, L.; Muccifora, S.; Barbieri, F.; Tassi, E.; Ruffini Castiglione, M.; Giorgetti, L. Genotoxicity of the food additive E171, titanium dioxide, in the plants Lens culinaris L. and Allium cepa L. Mutat. Res. Genet. Toxicol. Environ. Mutagenesis 2020, $849,503142$. [CrossRef] [PubMed]

41. Tarnavölgyi, G. Analysis of Consumers' Attitudes Towards Food Additives Using Focus Group Survey. Gábor TARNAVöLGYI 2003, 68, 193-196.

42. Hansen, J.; Holm, L.; Frewer, L.; Robinson, P.; Sandøe, P. Beyond the knowledge deficit: Recent research into lay and expert attitudes to food risks. Appetite 2003, 41, 111-121. [CrossRef]

43. Bearth, A.; Cousin, M.-E.; Siegrist, M. The consumer's perception of artificial food additives: Influences on acceptance, risk and benefit perceptions. Food Qual. Prefer. 2014, 38, 14-23. [CrossRef]

44. Nutrition Institute. Composition and Labelling Information System as a Tool for Monitoring of the Food Supply. Available online: https://www.nutris.org/en/composition-and-labelling-information-system (accessed on 12 December 2020).

45. Dunford, E.; Webster, J.; Metzler, A.B.; Czernichow, S.; Ni Mhurchu, C.; Wolmarans, P.; Snowdon, W.; L'Abbe, M.; Li, N.; Maulik, P.K.; et al. International collaborative project to compare and monitor the nutritional composition of processed foods. Eur. J. Prev. Cardiol. 2012, 19, 1326-1332. [CrossRef] [PubMed]

46. Pivk Kupirovič, U.; Miklavec, K.; Hribar, M.; Kušar, A.; Žmitek, K.; Pravst, I. Nutrient Profiling Is Needed to Improve the Nutritional Quality of the Foods Labelled with Health-Related Claims. Nutrients 2019, 11, 287. [CrossRef]

47. Zupanic, N.; Hribar, M.; Fidler Mis, N.; Pravst, I. Free Sugar Content in Pre-Packaged Products: Does Voluntary Product Reformulation Work in Practice? Nutrients 2019, 11, 2577. [CrossRef] [PubMed]

48. Agresti, A.; Brent, A.C. Approximate is better than "Exact" for interval estimation of binomial proportions. Am. Stat. 1998, 52, 119-126. [CrossRef]

49. Mintel Group Ltd. Mintel Global New Products Database. Available online: https://www.mintel.com/global-new-productsdatabase/features (accessed on 20 May 2021).

50. Mintel. Glossary 2016. Available online: https:/ / www.gnpd.com (accessed on 20 May 2021).

51. Watson, E. Food Colors: How Will EFSA's Decision on Titanium Dioxide Safety Impact the US Market? Available online: foodnavigator.com (accessed on 17 August 2021).

52. Huybrechts, I.; Sioen, I.; Boonb, P.E.; De Neve, M.; Amiano, P.; Arganini, C.; Bower, E.; Busk, L.; Christensen, T.; Hilbig, A.; et al. Long-term dietary exposure to different food colours in young children living in different European countries. EFSA Supporting Publ. 2010, 7, 53E. [CrossRef]

53. Bachler, G.; von Goetz, N.; Hungerbuhler, K. Using physiologically based pharmacokinetic (PBPK) modeling for dietary risk assessment of titanium dioxide (TiO2) nanoparticles. Nanotoxicology 2015, 9, 373-380. [CrossRef] [PubMed]

54. Sprong, C.; Bakker, M.; Niekerk, M.; Vennemann, M. Exposure Assessment of the Food Additive Titanium Dioxide (E 171) Based on Use Levels Provided by the Industry. Available online: https://rivm.openrepository.com/handle/10029/600597 (accessed on 17 August 2021).

55. Yin, C.; Zhao, W.; Liu, R.; Liu, R.; Wang, Z.; Zhu, L.; Chen, W.; Liu, S. TiO2 particles in seafood and surimi products: Attention should be paid to their exposure and uptake through foods. Chemosphere 2017, 188, 541-547. [CrossRef] [PubMed]

56. Morris, S. Dunkin' Donuts Drops Titanium Dioxide. Available online: https://sensientfoodcolors.com/en-us/industry-trends/ dunkin-donuts-drops-titanium-dioxide/ (accessed on 30 May 2021).

57. Sensient Food Colors. Avalanche, Purely Brilliant Titanium Dioxide Alternatives. Available online: https://sensientfoodcolors. com/en-us/color-solutions/avalanche/ (accessed on 30 May 2021).

58. Pravst, I.; Lavriša, Ž.; Kušar, A.; Miklavec, K.; Žmitek, K. Changes in Average Sodium Content of Prepacked Foods in Slovenia during 2011-2015. Nutrients 2017, 9, 952. [CrossRef] [PubMed] 